DOI: $\underline{10.35619 / \text { iiu.v1i14.413 }}$

Островський Олександр

викладач кафедри філології «українська мова та література» Закарпатського угорського інституту ім. Ференца Ракоці II, м. Берегово, Україна

ORCID: 0000-0003-0441-6866 e-mail: ostrovskisasha1985@gmail.com

\title{
ФОРМУВАННЯ МОВЛЕННСВОЇ КУЛЬТУРИ ТА ФАХОВОЇ МАЙСТЕРНОСТІ ВЧИТЕЛЯ В ПЕДАГОГІЧНІЙ СПАДЩИНІ
} В. СУХОМЛИНСЬКОГО

Аннотація. У статті значна увага приділяється ролі мови та літератури як засобу професійного i культурного спілкування, інтеграційній якості фахової майстерності особистості та інтелігентності.

Доведено, що значний внесок у розвиток методики української мови зробив великий i глибоко національний за духом педагог В. Сухомлинський, який за всієї розмаїтості інтересів і енциклопедичності знань, був передусім учителем української мови й літератури, а слово вважав головним інструментом освітнього процесу. Вивчаючи творчу спадщину В. Сухомлинського 3'ясовано, що педагог-новатор приділяв особливу увагу таким поняттям, як культура мовлення, риторика, етикет. Акцентується увага на вимогах В. Сухомлинського до культури спілкування та шляхах підвищення особистої культури мовлення вчителя, розвитку культури писемного та усного мовлення учнів у процесі навчальної та виховної діяльності. Учений вважав, що навички письма дитини мають бути доведені до напівавтоматичного рівня, а розумові сили учня повинні бути спрямовані на обмірковування викладу змісту та розуміння, а не на сам процес письма. Головне завдання вчителясловесника, за його переконанням, - виховати в учня любов до рідної мови. Вчитель повинен зробити рідне слово основою духовного зростання учня. На переконання В. Сухомлинського, рідна мова - одна-єдина для людини, тому іiі потрібно знати, берегти і збагачувати впродовж усього життя. Встановлено, що за В. Сухомлинським, письмо повинно стати засобом, ефективним інструментом освітньої праці. Розвитку особистості учнів сприяє розвиток культури писемного та усного мовлення, а під керівництвом учителя учні повинні працювати творчо, поглиблювати, розвивати та застосовувати на практиці свої мовні знання. Письменними учні стають тоді, коли навчилися користуватися словом і готові вміло використовувати його як засіб висловлення свого ставлення до подій i краси навколишнього світу. Щодо рідної мови В. Сухомлинський наголошує: «Дві рідні мови - це так само безглуздо, якби ми намагалися 


\section{Інноватика у вихованні. Випуск 14. 2021.}

уявити, що одну дитину народили дві матері. У дитини є одна мати. Рідна. До останнього подиху». Цими словами видатний педагог висловив своє педагогічне кредо, любов і повагу до рідної мови.

Ключові слова: В. Сухомлинський, учитель, мовна освіта, культура мовлення, фахова майстерність, розвиток особистості.

Постановка проблеми. Сучасні тенденції розвитку освіти в суспільно-політичних і економічних вимірах у всіх розвинених країнах спрямовані на посилення комунікабельних здібностей людини, створення умов для розвитку і самореалізації кожної особистості, виховання у неї комунікативної культури як необхідної умови інтеграції молодої людини у соціальні та виробничі процеси, формування потреби постійного підвищення професійної кваліфікації, мобільності та культури особистості. Слід усвідомлювати і те, що науково-технічний процес неперервно продукує нові професії, відповідно змінюється і насичується новою професійною термінологією мова, що супроводжується як змінами функції мови, так і формуванням нового рівня професійної культури. Нові професійні терміни і культура як складові змістової основи дозволяють логічно і лаконічно висловлювати думки та адекватно передавати сутність категорій та понять науки, техніки, виробництва, які створюються останнім часом. Сучасна термінологія $є$ показником наукового, соціальноекономічного і культурного розвитку розвинених країн і цивілізованих націй.

В умовах розбудови України та утвердження їі на міжнародній арені гостро постала потреба закріплення української мови як державної, зміцнення iï статусу, забезпечення використання в усіх сферах громадського i державного життя. Володіння літературною мовою, додержання iii норм в усіх, практично актуальних для сучасного спеціаліста, сферах спілкування - це невід'ємна частина професійної підготовки молодої людини до майбутньої діяльності.

Для розбудови української відносно молодої держави, їі науки й культури, формування національної свідомості народу, велике значення має творча спадщина видатних педагогів і методистів. Вагомий внесок у розвиток методики української мови зробив великий педагог, глибоко національний за духом, В. Сухомлинський (1918-1970рр.). За великої кількості інтересів i енциклопедичних знань у багатьох науках В. Сухомлинський насамперед був учителем української мови й літератури i ставився до слова як до головного інструменту освітнього процесу (Стельмахович,1988). Головне завдання словесника, на його переконання, - це виховати в учнів любов до рідної мови, яка - одна-єдина на все життя, тому треба знати, берегти, збагачувати іiі. У своєму записнику В.Сухомлинський занотовує: «Дві рідні мови - це так само безглуздо, якби ми намагалися уявити, що одну дитину народили дві матері. У дитини $\epsilon$ одна мати. Рідна. До смерті. До останнього подиху». Цими словами 


\section{Інноватика у вихованні. Випуск 14. 2021.}

видатний педагог висловив педагогічне кредо, любов і повагу до рідної мови (Савченко, 2003).

Аналіз останніх досліджень 3 проблеми. Особливості педагогічної діяльності педагога-новатора В. Сухомлинського розглядалися у працях М. Ярмаченка, М. Красовицького, О. Савченко, О. Сухомлинської, М. Сметанського, I. Зязюна, М. Антонця та інших. Методична спадщина В. Сухомлинського досить багатогранна і глибока: він торкається проблем формування мовної культури як учнів, так і вчителів-словесників, конкретних методичних питань щодо різних мовленнєвих рівнів. Серйозної уваги його ідеям в цьому напрямі приділяють А. Богуш, М. Вашуленко, Л. Мамчур, І. Баранюк та ін. (Сікорський, 2018, с.6-10).

Водночас проблематика розвитку культури мовлення вчителів та учнів у творчій спадщині В.Сухомлинського ще недостатньо досліджена, його новаторські ідеї щодо мовної освіти та пї ролі у формуванні особистості не втрачають актуальності та потребують детального аналізу і висвітлення.

Мета статті - дослідити погляди В. О. Сухомлинського на мову i слово в навчанні і вихованні, проблематику розвитку культури писемного мовлення учителів як вагомого засобу духовного розвитку особистості та акцентування уваги на особливостях формування професійної майстерності і мовленнєвої культури в процесі підготовки майбутніх учителів початкової школи у закладах вищої освіти.

Виклад основного матеріалу дослідження. Аналіз педагогічної спадщини В. Сухомлинського переконує, що освітня діяльність вченого спрямовувалася на те, щоб «...життєдайне джерело - багатство рідної мови - було відкрите для дітей з перших кроків їхнього життя». У багатьох його працях («Слово рідної мови», «Рідне слово», «Слово про слово» та ін) (Сухомлинський, 1964; 1977 a, С.201-216) знаходимо відповіді на актуальні питання: як навчити дитину сприймати, розуміти слово і вдало використовувати його в усному й писемному мовленні. Із живої думки і слова «...почалося становлення людини: мисль, втілена в слово, підняла нас над природою, над усіма речами і явищами, над епохами і століттями. Слово ввібрало в себе найтонші порухи наших почуттів; в ньому закарбувалася душа, звичаї, традиції, радості і болі народу - всі його духовні цінності, творені століттями».

Навчання мови В. Сухомлинський вважав найважливішою i найважчою в педагогічній практиці справою. На його переконання, викладати цей предмет повинні найбільш здібні і талановиті вчителі, оскільки на основі багаторічного особистого досвіду В. Сухомлинський дійшов висновку, що це не просто передача знань, практичних умінь, навичок, а «...це передусім виховання. Виховання розуму, формування думки, копітке різьблення й ліплення найтонших рис духовного обличчя людини. Викладання мови - це майстерність творення людської душі, бо воно є найніжнішим, найтоншим діткненням до серця дитини. Викладання мови - це людинознавство, бо в слові поєднуються думки, почуття, 


\section{Інноватика у вихованні. Випуск 14. 2021.}

ставлення людей до всього навколишнього світу. Викладання мови - це й суспільствознавство, бо в слові закарбовані століття життя й боротьби народу, його мужність і слава, надії й сподівання» (Сухомлинський, 1977, a). На його глибоке переконання, учитель повинен зробити рідне слово основою духовного світу дитини.

У книзі «Серце віддаю дітям» павлиський вчений-гуманіст зауважує: «Мова - духовне багатство народу. «Скільки я знаю мов, стільки разів я людина», - говорить народна мудрість. Та багатство, втілене в скарбниці мов інших народів, лишається для людини неприступним, якщо вона не оволоділа рідною мовою, не відчула їі краси. Чим глибше людина пізнає тонкощі рідної мови, тим тонша її сприйнятливість до гри відтінків рідного слова, тим більше підготовлений іiі розум до оволодіння мовами інших народів, тим активніше сприймає серце красу слова» (Сухомлинський,1969). Без любові до рідного слова неможлива любов до рідної землі, до своєї вітчизни. Тому у контексті сказаного В. Сухомлинський у книзі «Щоб у серці жила Батьківщина» стверджує: «Рідне слово - то невичерпне, життєдайне і невмируще джерело, з якого дитина дістає уявлення про навколишній світ, про свою родину, про своє село і весь наш край. Віками народ творив це багатство, відкладаючи у скарбницю рідної мови найдорогоцінніші перлини мислі, уяви, фантазії, пісні, казки» (Сухомлинський,1965). У вже згадуваній статті «Любов до рідного слова» В. Сухомлинський наголошує: «Рідна мова - це фундамент мислення й розумового розвитку». Своє розуміння сутті мови і слова педагог-патріот висловив так: «Я домагаюсь того, щоб кожного разу, коли я вводжу дітей у квітучий сад, ім'я якому - рідна мова, вони пізнавали красу однієї квітки - слова, образу. Щоб сторінка за сторінкою перед ними горталася величезна книга - пам'ять народу. Щоб до сердець дитячих доходили найпотаємніші грані краси слова. Ці заняття так я й називаю Двісті Квіток Рідної Мови. Це двісті зустрічей з садом рідного слова, двісті бесід про найтоншу в світі красу. Кожна бесіда - осягнення розумом i серцем великого духовного багатства нашого народу» (Сухомлинський, 1977 a, С.201-216).

Слово в житті кожної людини відіграє велику роль. Ми добираємо слова і формуємо фразу, через які доносимо свою думку до інших людей. Завжди потрібно пам'ятати про силу слова. Воно може як надихнути людину на великі справи, так і викликати в неї тривогу, депресію, а часом i агресію. Добре слово окрилить, грубе - нанесе рану, спровокує до певних вчинків. Мудрим словом можна запобігти багатьом бідам і неправильним, поспішним рішенням. Силою слова можна пробудити найкращі якості людської душі - милосердя, великодушність, доброту, щирість, співчуття, вміння прощати і любити! Саме до цього закликає нас видатний методист та митець слова (Сухомлинська, 2002).

Неоцінений його внесок у розвиток філософії професійного становлення педагога. Розвиваючи ідеї класиків світової педагогіки Я. А. Коменського , Ж. Ж. Руссо, К. Ушинського, Я. Корчака та інших, 


\section{Інноватика у вихованні. Випуск 14. 2021.}

В. Сухомлинський пов'язував вирішення широкого кола навчальновиховних завдань із високим рівнем професійної культури вчителя, вважаючи, що саме вчитель - це перший, а потім і головний наставник учня в інтелектуальному становленні та розвитку, він пробуджує в дитині жадобу до знань, повагу до науки, культури, освіти. До вчителя В. Сухомлинський ставив високі вимоги, називаючи цю професію людинознавством, розуміючи постійне проникнення вчителя у складний духовний світ учня. Досконале знання свого предмета, глибока любов до нього в поєднанні $з$ любов'ю до дитини, вміння впливати на іiі розум i почуття, спонукати до благородних почуттів, готовності прийти на допомогу, здатності до творчої праці, активної життєвої позиції, потреби у самовдосконаленні - це далеко не повний перелік тих рис і якостей, які хотів В. Сухомлинський бачити в «інженерів людських душ» (Сухомлинський, 1976 b, С.68-76).

Особливу увагу вчений зі світовим іменем приділяв педагогічній майстерності та педагогічній культурі вчителя. Саме ці дефініції він увів у вітчизняну педагогіку. В. Сухомлинський зазначав, що основу педагогічної культури «становлять: глибоке знання вчителем свого предмета, багатство методів вивчення особистості учня, педагогічна етика, педагогічна творчість, науково-дослідна робота вчителя, єдність науки й майстерності». У зв'язку з цим заслуговує на увагу позиція вченого щодо особистості викладача рідної мови. «Викладати цей предмет повинні найздібніші й найталановитіші. Бо це не просто передача знань, практичних умінь, навичок. Це передусім виховання. Викладання мови це майстерність творення людської душі, бо воно $є$ найтоншим, найніжнішим діткненням до серця людини. Викладання мови людинознавство, бо в слові поєднуються думки, почуття, ставлення людей до всього навколишнього світу» (Сухомлинський, 1977 а). Творче осмислення спадщини видатного українського педагога й методиста збагачує досвід роботи над словом на заняттях української мови. Заглиблюючись у його поради, побажання, переконуєшся, що кращої методики навчання рідної мови, як у В. Сухомлинського, по суті, нині немає. Варто лише опанувати іiі й уміло використовувати на практиці та пам'ятати вислів Арістотеля, «Успішний учитель - це той, учні якого досягли в житті значно більшого успіху, ніж він сам». Сам В. Сухомлинський бачив у мові могутній чинник становлення всебічно розвиненої особистості, дієвий засіб духовного зростання нашого суспільства (Савченко,2011). 3 розвитком мови, з оволодінням культурою мовлення він нерозривно пов'язував розвиток розуму, формування думки, копітке різьблення найтонших рис духовного обличчя людини. «Мовна культура, - за словами В. Сухомлинського, це живодайний корінь культури розумової, усього розумового виховання, високої, справжньої інтелектуальності. Завдяки мові людині стають доступні найрізноманітніші джерела, що живлять емоційну, інтелектуальну й вольову сферу іiі духовного життя. У мові відбивається ідейна 


\section{Інноватика у вихованні. Випуск 14. 2021.}

спрямованість духовного життя людини, слово містить у собі невичерпні можливості для впливу на їі світоглядну сферу». Поняття «культура мови» В. Сухомлинський не зводив до вузькопрактичної мети живого спілкування, а вкладав у нього глибокий зміст. Таке трактування ролі культури слова у житті людини випливає 3 широти суспільної функції мови. Вчений писав: «... із думки і слова почалося становлення людини; мисль, втілена в слово, підняла нас над природою, над усіма речами й явищами, над епохами й століттями. Слово ввібрало в себе найтонші порухи наших почуттів; у ньому закарбувалася душа, звичаї, традиції, радості й болі народу - всі його духовні цінності, творені століттями» (Сухомлинський, 1977 b).

Вчений переконаний, що оволодіє мовою той, хто постійно прагне цього та орієнтується на мовний взірець. За його порадою, тільки читаючи твори письменників-класиків, молодь може збагатити свій лексичний запас, відчути багатство української мови та гнучкість лексичного вибору. У цьому процесі важливу роль відіграє самовиховання, яке дисциплінує думку, спонукає запам'ятовувати й складати самостійно довершені мовні зразки, відкидати недолугі вислови. Мовне самовиховання обов'язково приведе до словника - наймогутнішого чинника мовного самовдосконалення. «У школі, у сім’і, у житті кожної людини повинен бути культ книги», - невтомно повторював видатний педагог, бо бачив у начитаності головну засаду піднесення культури мови.

В. Сухомлинський завжди відстоював думку, що невід’ємною складовою культури мови $є$ етика живого спілкування і ввічливі стосунки між людьми, з дотриманням людської порядності та гідності. За словами вченого: «Слово - найтонше доторкання до серця, - воно може стати i ніжною запашною квіткою, і живою водою, що повертає віру в добро, i гострим ножем, і розжареним залізом, і брудом. Мудре і добре слово дає радість, нерозумне і зле, необдумане і нетактовне - приносить біду. Словом можна вбити й оживити, поранити й вилікувати, посіяти тривогу й безнадію і одухотворити, розсіяти сумнів і засмутити, викликати посмішку і сльози, породити віру в людину і заронити невіру, надихнути на працю і скувати силу душі...» (Сухомлинський, 1977).

Для В. Сухомлинського культура мови це, насамперед, і культура людських відносин, він пише: «Ми часто говоримо один одному: бажаю тобі всього доброго, бажаю тобі добра і щастя. Це не тільки вияв ввічливості. У цих словах ми виявляємо свою людську сутність. Уміння відчувати, вміння по-хорошому бачити навколишніх людей - не тільки показник етичної культури, а й результат величезної внутрішньої духовної роботи. Щиросердне бажання добра невіддільне від самовиховання... Ми говоримо один одному: здрастуйте, доброго вам здоров'я. У цих словах криється глибокий моральний зміст, у них - сама сутність доторкання душі до душі. Цим ми висловлюємо своє ставлення до найбільшої цінності людини. Не сказати людині здрастуйте значить виявити своє моральне невігластво. Тонка грань людських відносин захована в словах Здрастуйте, 


\section{Інноватика у вихованні. Випуск 14. 2021.}

Добрий день. Слово здрастуйте має чудодійну властивість - воно пробуджує почуття взаємного довір'я, зближує людей, відкриває їх душі. Бути здоровим - це не просто жити, бачити світ навколо себе й ставитися до нього певним чином... Бути здоровим - відчувати радості життя, найважливішою з яких є спілкування з людиною» (Сухомлинський, 1966). Для виховання мовної культури за В. Сухомлинським дуже важливо, щоб людей і в особистих, і в колективних стосунках об'єднували прагнення добра і віри в краще майбутнє. Згадана грань людських відносин знайшла яскраве відображення у всіх народів у словах ввічливості, якими вони користуються упродовж всієї історії існування людства. Вміння користуватися словами добрих побажань у живому щоденному спілкуванні - важлива ознака мовно-етичної культури і водночас основа гуманності, без якої людству загрожує невігластво (Кравцов,2004).

Фундаментальне тлумачення мовної культури, яка охоплює не лише вміння розмовляти українською мовою з дотриманням усіх літературних норм, а й ввічливість та доброзичливість спілкування між людьми, коли сказане слово несе позитивну енергетику та наповнене любов'ю до людини та рідної мови, свідчить про всепланетарну значущість вчення В. Сухомлинського.

Наголосимо на тому, що українсько-російська двомовність, яка сформувалася в Україні під впливом історично-політичних чинників i набула великого звучання останніми роками, турбувала вченого ще у перші післявоєнні десятиліття. В. Сухомлинський бачив цю проблему та однозначно акцентував увагу на такому: «Кожне слово має своє значення, невміння вибрати потрібне слово - це те саме, що замість гостро заструганого олівця на уроці малювання користуватися цвяхом» і далі «Особливу тривогу викликає те, що молоді люди, які вважають себе навіть культурними, у побуті, буває, користуються такою жахливою сумішшю двох мов, що якби написати отут кілька прикладів з їхньої «мови», то, мабуть, папір не витримав би сорому - загорівся б... Користування сумішшю 3 двох мов - це одно $з$ найтривожніших явищ... Говорити такою скаліченою мовою - це все одно, що грати...на розстроєній скрипці. Все одно, що 3 дерева красуню різьбити...тупою щербатою сокирою» (Сухомлинський, 1977 b.). Наше сьогодення вимагає, аби всі жителі України мали добрі знання української мови, дотримувалися правил мовного культурного спілкування, бо часто під впливом російської мови молодь, як слід, не володіє ні українською, ні російською мовою.

Праці, ідеї, думки, досвід відомого педагога В. О. Сухомлинського повною мірою відповідають потребам сучасної початкової школи, допомагають у вирішенні складних завдань модернізації освіти. Видатний педагог-гуманіст був глибоко переконаний у тому, що «все шкільне життя повинно бути пройняте духом гуманності», що лише створення атмосфери довіри, допомоги, справедливого ставлення, вимогливості і такту може забезпечити справжню гуманізацію навчально-виховного процесу. Основи особистісно-орієнтованої системи навчання i виховання, яка нині 


\section{Інноватика у вихованні. Випуск 14. 2021.}

утверджується у школах України, без сумніву, закладені в педагогіці В. О. Сухомлинського.

Велику увагу він приділяв проведенню уроків мислення, зокрема уроків серед природи. Він писав «Уроки серед природи - це подорожі до джерел живої думки, під час яких учні самостійно читають сторінки найчудеснішої в світі книги - книги природи». В. Сухомлинський стверджував «Школа стає справжнім осередком культури лише тоді, коли в ній панують чотири культи: «культ Батьківщини, культ Людини, культ Матері, культ Слова». У всіх своїх працях і порадах вчений-педагог рекомендував вчити дітей думати, творити, фантазувати серед чудової краси природи, що є джерелом думки й слова, створювати на полі, в саду, на ставку свої власні казки, оповідання, вірші на основі спостережень і міркувань (Сухомлинський, 1976 b, С. 55-206).

Творче осмислення спадщини видатного українського педагога й методиста В. Сухомлинського збагачує досвід роботи над словом на заняттях української мови і літератури. Заглиблюючись у його поради, побажання, настанови, переконуєшся, що кращої методики навчання рідної мови як у Василя Олександровича Сухомлинського, по суті, нині немає. Варто лише опанувати iї й уміло використовувати на практиці. Сучасна реформа української освіти покликана сприяти цьому процесу. Творчо використовуючи ідеї В. Сухомлинського про роль мовлення та мислення у розвитку особистості учнів, її почуттів, сучасна українська школа та вчителі мають можливість за рахунок використання нових інформаційно-комунікаційних технологій розширити і збагатити досвід вихованців у цій сфері.

Висновки і перспективи подальших розвідок. Видатний вчений i практик В. Сухомлинський приділяв особливу увагу розвитку культури писемного і усного мовлення учнів у процесі навчальної та виховної діяльності у середній школі. Він вважав, що письмо освіченої молодої людини повинно бути напівавтоматичним; що розумові зусилля сформованої особистості мають бути спрямовані на розуміння змісту, обмірковування, а не на процес письма; що письмо має стати засобом, інструментом навчальної праці; що для розвитку культури писемного мовлення всі, хто вчиться, повинні працювати творчо. На його тверде переконання для цього потрібні фахово підготовлені вчителі української мови і літератури. Розроблена ним система та методичні поради щодо формування мовленєвої культури в школі ввійшли до педагогічної скарбниці людства.

Успішність та ефективність розвитку культури писемного і усного мовлення майбутніх учителів, на наш погляд, може суттєво підвищити при систематичному і глибокому вивченні в ЗВО педагогічних ідей і праць В. Сухомлинського з цієї проблематики. 


\section{СПИСОК ВИКОРИСТАНИХ ДЖЕРЕЛ}

Бех, І. (2006). Виховання особистості. Сходження до духовності. Київ: Либідь. 273 с.

Кравцов, В.(2004). Вимоги до професійної культури вчителя в педагогічній спадщині В.О.Сухомлинського/ Педагогіка і психологія. Вісник АПН України. № 1(42). C.21-31.

Савченко, О. (2003). Гуманізм педагогіки Василя Сухомлинського. Ocвima Украӥни. 19 серп. (№ 62/63). с. 5.

Савченко,О. (2011). Розвиток творчості школяра - стрижнева проблема творчості В.О.Сухомлинського. Донецьк: Витоки. С.17-22.

Сікорський, П., Герцюк, Д. (2018) Василь Сухомлинський: наук.праці. Львів: Бадікова Н.О. 252 с.

Стельмахович, М.(1988). Видатний творець методики вивчення української мови. Укр.мова і літ.в шк. № 9. С.52-60.

Сухомлинська, О. (2002). Філософія для дітей як педагогічна проблема. URL: http://library.udpu.org.ua/library_files/psuh_pedagog_probl_silsk_shkolu/2/visnuk_1.pd f [Дата звернення 10.08.2021].

Сухомлинський, В (1964). Слово про слово. Радянська Украӥна. 16 січня.

Сухомлинський В. О. (1965). Щоб у серці жила Батьківщчина. Київ: Знання. $80 \mathrm{c}$.

Сухомлинський, В. (1966). Моральні заповіді дитинства $і$ юності. Київ: Радянська школа. 230 с.

Сухомлинський, В. (1968). Слово рідної мови// Украӥнська мова і література в школі. №12. С. 1-10.

Сухомлинський, В. (1969). Серце віддаю дітям. Київ. 245 с.

Сухомлинський, В. (1976 а). Вибрані твори в 5 m. T. 1. Київ: Радянська школа. $653 \mathrm{c}$.

Сухомлинський, В. (1976 b). Вибрані твори в 5 m. T. 2. Київ: Радянська школа. $669 \mathrm{c}$. $669 \mathrm{c}$.

Сухомлинський, В. (1977 а). Вибрані твори в 5 m. T. 3. Київ: Радянська школа.

Сухомлинський В.О. (1977 b). Вибрані твори в 5 m. T.5. Київ: Радянська школа. 638 с.

\section{REFERENCES}

Bekh, I. (2006). Vykhovannia osobystosti. Skhodzhennia do dukhovnosti [Education of personality. Ascent to spirituality]. Kyiv: Lybid. 273 s. [in Ukrainian].

Kravtsov, V.(2004). Vymohy do profesiinoi kultury vchytelia v pedahohichnii spadshchyni V.O.Sukhomlynskoho [Requirements for the professional culture of teachers in the pedagogical heritage of VO Sukhomlinsky]. Pedahohika i psykholohiia. Visnyk APN Ukrainy. No 1(42). S.21-31. [in Ukrainian].

Savchenko, O. (2003). Humanizm pedahohiky Vasylia Sukhomlynskoho [Humanism of pedagogy of Vasyl Sukhomlynsky]. Osvita Ukrainy. 19 serp. (No 62/63). s. 5. [in Ukrainian].

Savchenko,O. (2011). Rozvytok tvorchosti shkoliara - stryzhneva problema tvorchosti V.O.Sukhomlynskoho [The development of schoolchildren's creativity is the core problem of V.O. Sukhomlinsky's creativity]. Donetsk: Vytoky. s.17-22. [in Ukrainian].

Sikorskyi, P., Hertsiuk, D. (2018) Vasyl Sukhomlynskyi: nauk.pratsi [Vasyl Sukhomlynskyi: scientific works]. Lviv: Badikova N.O. 252 s. [in Ukrainian]. 


\title{
Інноватика у вихованні. Випуск 14. 2021.
}

Stelmakhovych, M.(1988). Vydatnyi tvorets metodyky vyvchennia ukrainskoi movy [An outstanding creator of the methodology of teaching the Ukrainian language]. Ukr.mova i lit. v shk. No 9. s.52-60. [in Ukrainian].

Sukhomlynska, O. (2002). Filosofiia dlia ditei yak pedahohichna problema. [Philosophy for children as a pedagogical problem]. URL: http://library.udpu.org.ua/library_files/psuh_pedagog_probl_silsk_shkolu/2/visnuk_1.pd f. [Data zvernennia 10.08.2021]. [in Ukrainian].

Sukhomlynskyi, V. (1964). Slovo pro slovo [Word for word]. Radianska Ukraina. 16 sichnia. [in Ukrainian].

Sukhomlynskyi V. O. (1965). Shchob u sertsi zhyla Batkivshchyna. [Let the Motherland live in the heart]. Kyiv: Znannia. 80 s. [in Ukrainian].

Sukhomlynskyi, V. (1966). Moralni zapovidi dytynstva i yunosti [Moral precepts of childhood and adolescence]. Kyiv: Radianska shkola. 230 s. [in Ukrainian].

Sukhomlynskyi, V. (1968). Slovo ridnoi movy [The word of the native language]. Ukrainska mova i literatura $v$ shkoli. No 12. s. 1-10. [in Ukrainian].

Sukhomlynskyi, V. (1969). Sertse viddaiu ditiam [I give my heart to children]. Kyiv. 245 s. [in Ukrainian].

Sukhomlynskyi, V. (1976 a). Vybrani tvory v 5 t. T. 1. [Selected works in 5 vol. Vol. 1]. Kyiv: Radianska shkola. 653 s. [in Ukrainian].

Sukhomlynskyi, V. (1976 b). Vybrani tvory v 5 t. T. 2. [Selected works in 5 vol. Vol. 2]. Kyiv: Radianska shkola. 669 s. [in Ukrainian].

Sukhomlynskyi, V. (1977 a). Vybrani tvory v 5 t. T. 3. [Selected works in 5 vol. Vol. 3]. Kyiv: Radianska shkola. 669 s. [in Ukrainian].

Sukhomlynskyi V.O. (1977 b). Vybrani tvory v 5 t. T.5. [Selected works in 5 vol. Vol. 5]. Kyiv: Radianska shkola. 638 s. [in Ukrainian].

\section{FORMATION OF SPEECH CULTURE AND TEACHER'S PROFESSIONAL SKILLS IN V. SUKHOMLYNSKYI'S PEDAGOGICAL HERITAGE}

\author{
Olexandr Ostrovskyi \\ Lecturer at the Department of Philology \\ "Ukrainian Language and Literature" \\ Ferenc Rakoczi II Transcarpathian Hungarian Institute, \\ Berehovo, Ukraine \\ ORCID: 0000-0003-0441-6866 \\ e-mail: ostrovskisasha1985@gmail.com
}

\begin{abstract}
In the article much attention is paid to the role of language and literature as a means of professional and cultural communication, the integration quality of cultural and professional skills of the individual. It is shown that a significant contribution to the development of Ukrainian language methodology was made by a great and deeply national in spirit, teacher V. Sukhomlynskyi, who for all the diversity of interests and encyclopedic knowledge, was primarily a teacher of Ukrainian language and literature and treated the word as the main educational process. As a result of studying the creative heritage of V. Sukhomlynskyi, it was found that the teacher-innovator paid special attention to such concepts as "speech culture", "rhetoric", "etiquette". Emphasis is placed
\end{abstract}




\section{Інноватика у вихованні. Випуск 14. 2021.}

on the requirements of V. Sukhomlynskyi to the culture of communication and ways to improve the personal culture of speech of the teacher, the development of the culture of written and oral speech of students in the process of teaching and educational activities. The scholar believed that a child's writing skills should be brought to a semi-automatic level, and the student's mental strength should be focused on reflection on the content and understanding, and not on the writing process itself. The main task of the teacher, in his opinion, is to instill in the student a love for the native language. The teacher must make the native language the basis of the student's spiritual growth. According to V. Sukhomlynsky, the native language is the only one for a person, so it needs to be known, preserved and enriched throughout life. It is established that according to V. Sukhomlynsky, writing should become a means, an effective tool of educational work. The development of students' personality is promoted by the development of the culture of written and oral speech and under the guidance of the teacher students must work creatively, deepen, develop and apply in practice their language skills. Students become literate when they have learned to use the word and are ready to skillfully use it as a means of expressing their attitude to events and the beauty of the world around them. Regarding the native language, V. Sukhomlynsky notes: "Two native languages are just as meaningless if we tried to imagine that one child was born to two mothers. The child has one mother. Native. Until the last breath". With these words the outstanding teacher expressed his pedagogical credo, love and respect for the native language.

Keywords: V. Sukhomlynskyi, teacher, language education, speech culture, professional skills, development of personality.

Стаття надійшла до редакиії 27.09.2021p. 